\title{
青色顔料を混合した樹脂によるポア観察について
}

\author{
高橋 学 ${ }^{* 1}$ ・薛 自求 ${ }^{* 2} \cdot$ 大和田朗 ${ }^{* 3} \cdot$ 石島洋二*4

\section{On the Study of Interconnected Pore Network using a Blue Dyed Epoxy Impregnated Thin Section}

\begin{abstract}
Manabu TAKAHASHI ${ }^{* 1}$, Ziqiu XUE*2, Akira OOWADA*3 and Youji ISHIJIMA*4

Key words : 孔隙 pore, 微細構造 microstructure, 薄片 thin section, 画像処理 image analysis

Abstract

To clarify interconnected pore network, blue dyed epoxy impregnated thin sections of various rocks were prepared. Careful microscopic photographic studies of thin sections were able to distinguish pores from grains. Pores are measured clearly by the presence of blue dyed epoxy. This blue dyed epoxy impregnation method was most suitable for rocks with porosity above a few percent, and for fractured rocks with ultimate fracture planes. Specific microcracks with width above 10 micron meter are detected clearly in granitic rocks.

Using an image processing technique, porosities and aspect ratios of pore were estimated from the segmented microsections. Porosities measured from the image, in general, different from that of the physical tests. The porosity of the Shirahama sandstone decreased by about $2 \%$ after stressed to $49 \mathrm{MPa}$. The low aspect ratio pores of the Shirahama sandstone closed completely after stressed to $49 \mathrm{MPa}$.
\end{abstract}

\section{1.はじめに}

岩石の初期構造や種々の応力条件下でのマイクロクラ ック進展の様子は, 薄片を光学顕微鏡で観察するという 方法で行われた1) 11)。この手法は岩石学や鉱物学の分

*1 通産省工業技術院地質調査所環境地質部 Environmental Gelogy Department, Geological Survey of Japan.

*2 北海道大学大学院工学研究科 Graduate Student, Faculty of Engineering, Hokkaido University.

*3 通産省工業技術院地質調査所地質標本館 Geological Museum, Geological Survey of Japan.

*4 北海道大学工学部資源開発工学科 Faculty of Engineering, Hokkaido University.
野で発達したものであり，現在でも日常的に用いられる 手法である。その後, 岩石の構造を直接観察する方法と して, SEM (走査型電子顕微鏡, Scanning Electron Microscope）が用いられるようになる。イオン研磨を 用いる SEM では, 岩石の薄片を用いる偏光顕微鏡と比 較すると以下のような利点が挙げられる。

·高倍率で 3 次元的な分解能を有している。

・薄片を作るときのような研磨剤による摩耗, 鉱物粒子 の脱落, 作業中に生じる 2 次クラックの生成を回避 できる。 岩石の初期構造を明らかにするために, SEM を最初 に用いたのは WEINBRANDT and FATT ${ }^{12)}$ である。そ の後, 数多くの研究者が岩石の構造やマイクロクラック 
進展の様子を調べるために積極的に SEM による観察を 実施した ${ }^{13) \sim 21) 。 ~}$

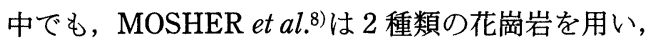
引っ張りあるいは压縮応力下の龟裂進展を顕微鏡で観察 した。また, BATZLE et al. ${ }^{22)}$ は Westerly 花崗岩を供 試体として加圧下における SEM 観察をひずみ計測と同 時に行った。従来の研究では, 除荷した後に観察を行わ

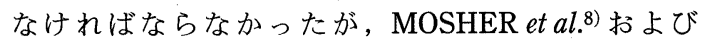

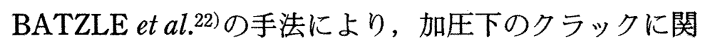
する正確な情報を得ることができるようになった。

これらとは別に，岩石内のマイクロクラックをより明 確に把握するために, 蛍光染料を用い, 紫外線照射をす ることによりクラックを明瞭化する方法も行われ た23),24)。西山ほか25) は蛍光剤扔よび染色剂を樹脂（メ チルメタアクリレート）に混合し, 岩石中の 2 次元的 なクラックネットワークを抽出している。画像処理した 後, 定量的な議論をし, $6 \%$ 以下の有効空隙率において は割れ目長さと有効空隙率との間に正の相関が成立する ことを述べている。画像処理の技術が進歩している現 在, 西山ほか25)による成果は, 岩石中のマイクロクラ ックの数や寸法およびそれらから推定される有効空隙率 等の定量的な検討を可能にしたと言える。

岩石内の流体の輸送特性は岩石内のポアやクラックの 形状, 連結性などの影響を強く受ける。SEM では, こ れらのポアやクラックの 3 次元的で分解能の高い形態 に関する情報は得られるが, 流体が通過したかどうかに 関する情報は得られない。一方, 顔料で着色した粘性の 低い樹脂を岩石内のポアやクラックの奥部まで浸透さ せ, 薄片にした後, 影微鏡観察する手法では, 薄片中に 観察される着色した樹脂の領域が透水試験などで流体が 通過した可能性のあるポアやクラックと考えることがで きる。このような方法では，流体が浸透した状態が明瞭 に認められる点に大きな特徵があり, さらに, ポアやク ラックを着色することにより，画像処理によるデータ処 理の可能性を高めている。

そこで, 従来の偏光䫓微鏡を用い, 青色顔料を混合し た樹脂を岩石内に注入し，薄片にした観察から，どの程 度岩石内のポアやクラックに関する情報が得られるのか を検討してみる。本文では，薄片作製の工程について詳 しく述べ, 砂岩・泥岩・花崗岩・大理石等 8 岩種の具 体的な適用事例を紹介する。その後，砂岩などの比較的 孔隙率の大きな岩石の薄片写真をもとに画像処理し, 染 色されたポアの分布や棈円近似した場合のアスペクト比 （楕円の長軸に対する短軸の比）の分布について，その 結果を紹介する。

\section{2. 薄片の作り方}

採取された試料の鉱物粒子などの脱落を防止するた め, 試料を切断する前の事前処理が必要となる。それに はをず，固結樹脂の適正を考慮しながら，顔料との相性 など最適なものを選ばなければならない。その条件とし $\tau$,

・硬化前粘性が低く, 岩石に含浸しやすいもの

・製作中の使用温度に耐えられるもの

. 青色顔料（EST-2611BLUE）と混合してもその樹脂 の性質が変化しないもの

これらの条件を満たす樹脂としてエポキシ系樹脂ペト ロポキシ154を選定した。以下に各工程について詳しく 述べる（図-1参照)。

\section{【工程 - 1】}

試料を $55-60^{\circ} \mathrm{C} に$ 保たれた真空乾燥器に入れ, 約 50 時 間試料内部の水分除去を行う。こうして得られた試料に 青色顔料混合樹脂を図-1(1)のように真空乾燥器を用い て真空含浸させる。器内温度を $55-60^{\circ} \mathrm{C}$ に保持したの は, 樹脂の粘性低下を図り, 試料に樹脂を含浸しやすく するためである。なお，他のエポキシ系樹脂はこの温度 の範囲内では約15分から20分の時間内で硬化促進され るが，今回使用した樹脂（ペトロポキシ154）は時間硬 化型ではなく, 熱硬化型であり, $80^{\circ} \mathrm{C}$ 以下では完全硬 化は望めず，著しい粘性低下を示すだけである。この状 態で, 180分間の真空加熱を行い, 試料を器内から取り 出し, $90^{\circ} \mathrm{C}$ 恒温ホットプレート上に 60 分間放置し, 樹脂の完全硬化を計った。

\section{【工程-2】}

樹脂硬化後の試料を電動ダイヤモンドソーで縦 $50 \times$ 横 $30 \times$ 厚さ $10 \mathrm{~mm}$ に整形する（図-1 (2)参照)。この 際, ダイヤモンドソーの冷却潤滑剂としてオイル（ダフ ニーカットHL25）を使用した。むた，試料内外部に付 着したオイルを除去するため， $70^{\circ} \mathrm{C}, 50$ 時間の真空乾 燥を実施した。切断の際, オイルを使用したのは, オイ ルが水に比べ, 試料に衝撃を与えず, 鉱物粒子の脱落防 止に優れているためである。

\section{【工程-3】}

摺りガラスを貼付する試料面を工程 -1 の要領でさら に真空含浸させた後（図-1(3)), グリーンカーボラン ダム\#800を用いて試料を研磨する。摺りガラスの必要 性は，透明なスライドガラスに比較してその表面が微小 な凹凸となっており，試料と樹脂との接着面積が大きく なるためである。むた, 摺りガラスの表面は透明スライ ドガラスのものより平行度が出ているので, 試料面の平 


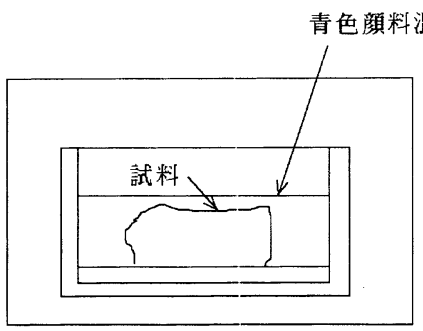

真空乾燥器

（1）試料を青色顔料混合樹脂で満たされた容器内に入 れ, 容器ごと真空含浸させる。

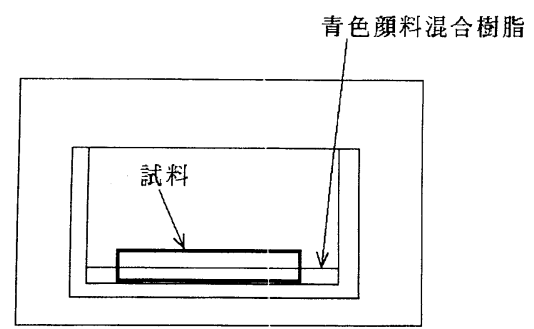

真空乾燥器

（3）さらに, 青色顔料混合樹脂を真空含浸させる。

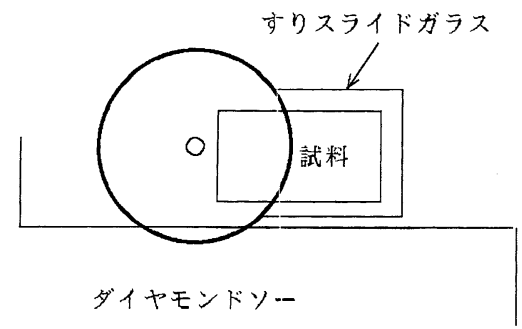

（5）ダイヤモンドソーで摺りガラス付き試料を 2 次切断 する。

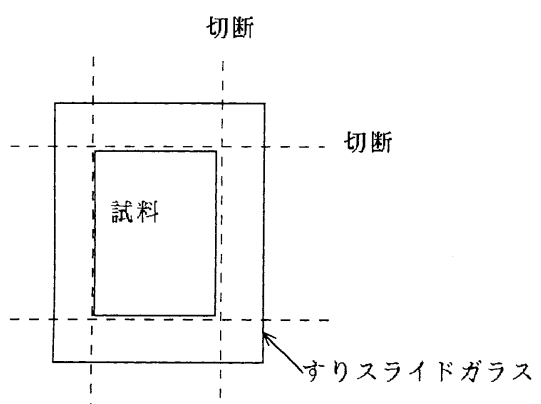

（7）摺りガラスのカット，およびスライドガラスの貼付

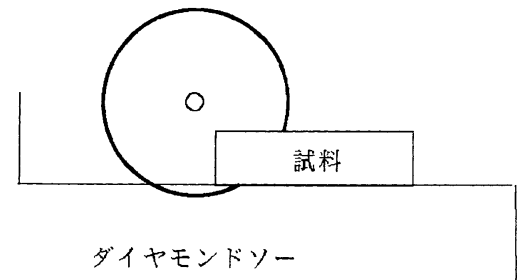

(2) ダイヤモンドソーで試料を $50 \times 30 \times 10 \mathrm{~mm}$ に切断 する。

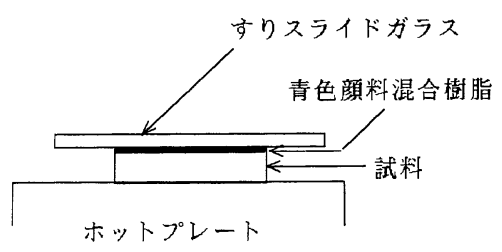

（4）摺りガラスと試料を接着させる。

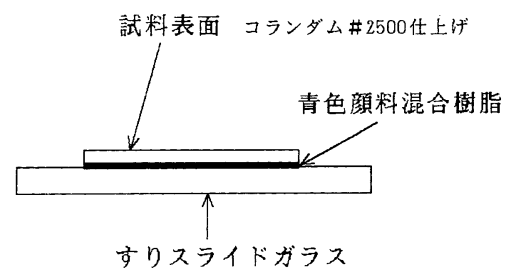

(6) (5)の試料をグリーンカーボランダム\# 400, \#800, コランダム\# 2500 で研磨し，厚さを約 60 ミクロンと する。

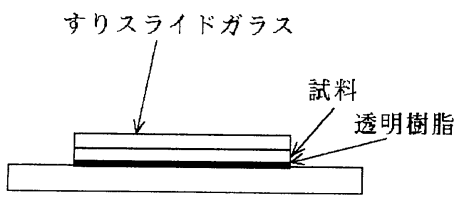

透明スライドガラス

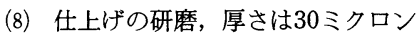

図 - 1 薄片作製工程 
行度を上げる場合に有効となる。

\section{【工程 -4】}

摺りガラスと試料との貼付工程にはいる。通常の薄片 作製手順と同様, $90^{\circ} \mathrm{C}$ に加熱したホットプレート上で 摺りガラスと試料との間の樹脂から発生する気泡を完全 に取り除きながら完全硬化させる（図-1(4)参照)。こ の際の樹脂には青色顔料を混合したものを用いる。

\section{【工程 - 5】}

樹脂の硬化後, 室温放置し, 冷却後ダイヤモンドソー を使用し，摺りガラス貼付試料の厚さが $1 \sim 2 \mathrm{~mm}$ にな るように 2 次切断する（図-1 (5)参照)。孔隙率が大き い岩石では，鉱物粒子の脱落などが考えられ，そのよう な危険性がある場合には, 再度工程 -3 を繰り返して実 施する。

\section{【工程 -6】}

2 次切断した試料を $60^{\circ} \mathrm{C}$ で真空乾燥し, グリーンカー ボランダム\# 800 で研磨し, 厚さを 100 ミクロンとする。 コランダム\#2500とオイルを用いて, 石英ガラス板上 で手作業研磨する（図-1(6)参照）。この段階での試料 の厚さは約 60 ミクロンとなる。

\section{【工程 -7】}

試料周囲の余分な摺りガラスをダイヤモンドガラスペ ンで切断し, 透明エポキシ樹脂を使用し, 工程 -4 の要 領で, 透明なスライドガラスに貼付する（図-1(7)参 照)。

\section{【工程 -8】}

普通薄片と同様の手順で作業を進める。カーボランダ

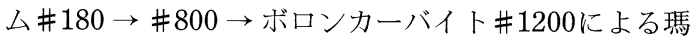
瑙板上手摺り（図 -1 (8)参照)。\#180は摺りガラスの研 磨のみに用いた。また, 切断研磨の際に使用する冷却潤 滑液抢よび洗浄に関してはすべてオイルを用いた。こう して完成した薄片の厚さは 30 ミクロンとなる。

以上薄片作製工程について述べた。この手法は安 部26)により着手された手法であり，この間種々の改良 が加えられている。特に, 工程中の鉱物粒子の脱落に関 しては注意深い作業と処理により, 現在ではほとんど生 じなくなるまでになった。

\section{3. 顕微鏡写真}

既述した作製方法で薄片を準備し，偏光顕微鏡写真を 具体的に以下に示し, ポアやクラックの分布の様子を見 ることにする。同手法が適用できる岩石とそうでない岩 石が以下の写真から明らかとなる。

写真 -1 は島根県産新第三紀来待砂岩のインタクトな
場合の写真である。来待砂岩の典型的なポアの様子が示 されている。ポアの周囲にはモルデン沸石が明瞭に認め られる。写真 $-2,3$ は同岩石を静水圧が $40 \mathrm{MPa}, 150$ MPa に至るまでそれぞれ負荷した場合の写真である。 静水圧の影響により，ポアを示す青色の部分が減少して いることが認められる。本手法の最大のメリットは, ポ アに浸透した着色樹脂が複雑なポアの形状を明瞭にし し かも容易に視覚化させえた点にある。来待砂岩中のモル デン沸石に関しては, 静水圧を $150 \mathrm{MPa}$ まで負荷して も，破壊したという明確な証拠は見つけることができな かった。

写真 -4 は真三軸試験後の和歌山県産新第三紀白浜砂 岩の主破断面近傍を示している。なお，本文では供試体 全体に生じた大きな破断面を主破断面と呼び，小さなも のと区別することにする。白浜砂岩は孔隙率が $13 \%$ あ り, 来待砂岩と比較すると粒子が小さく, 孔隙率も小さ いことが認められる。主破断面は比較的滑らかであり，

粒子サイズ程度の凹凸も確認できない。主破断面から派 生しているやや細い破断面には粒子サイズの凹凸が確認 できる。また，粒子が破砕された様子が認められる。こ のような主破断面と派生した破断面との滑らかさの違い は, 破壊時の変形量の違いによるものと思われる。すな わち, 破壊時の解放エネルギ一量が大きく変形量が大き いほど, 破断面の凹凸は摩耗により小さくなるからであ る。な抢，主破断面間に破砕された粒子が認められない のは, 試験後の取り扱い中に紛失したためである。

写真 -5 は透水係数に及ぼす中間主応力の影響を調べ た白浜砂岩の薄片写真であり, 写真の上下・左右方向は 中間一最小主応力方向に一致する。最小主応力は 15 $\mathrm{MPa}$ ，最大・中間主応力をそれぞれ $15 \mathrm{MPa}$ か 565 $\mathrm{MPa}$ まで変化させた供試体であり, 主破断面は生じて いない。この写真だけからでは, 中間主応力や最小主応 力がポア分布に与える影響を直接確認できないが，画像 処理によって得られたデータをもとに後に詳しい議論を することにする。

写真 -6 は新第三紀幌延泥岩の静水圧透水試験後のも のである。破断面がほぼ同じ方向に平行に入り, かつマ トリックス中にも小さな空隙が散在しているのが認めら れる。薄片全体の観察結果から, 各破断面が平行に, か つそれぞれ連結することなく存在し，結果として主破断 面の存在が認められない。以上述べた来待砂岩, 白浜砂 岩, 幌延泥岩の変形特性と透水特性に関しては, 薛ほ か27)，石島ほか28),29)に詳しく述べられている。

写真 - 7, 8 はインタクトな和泉砂岩のものである。和 泉砂岩は大阪府海南町産中世代白亜紀の細粒砂岩であ 


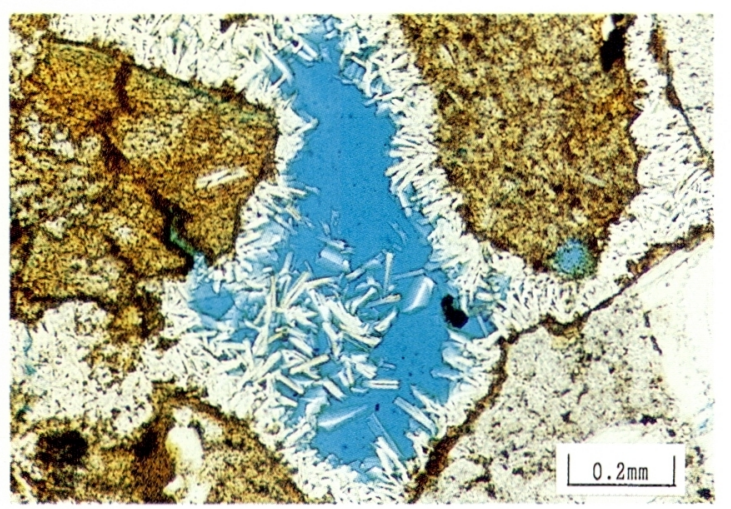

写真 - 1 インタクトな来待砂岩の薄片写真

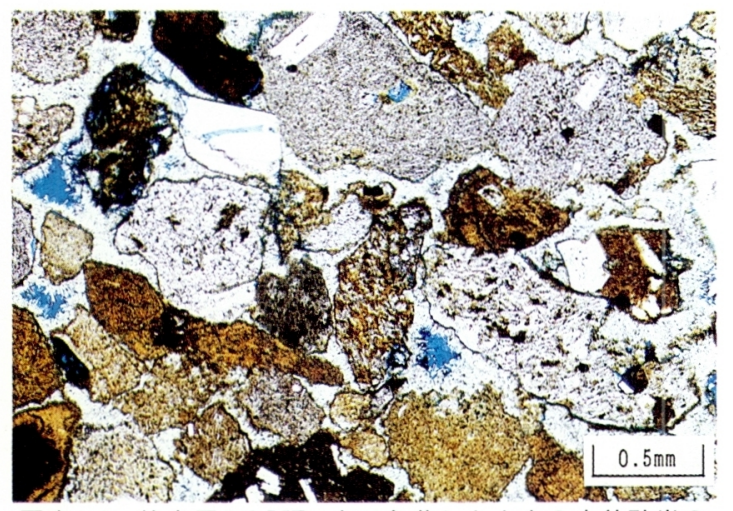

写真 -3 静水圧 $150 \mathrm{MPa}$ まで負荷したときの来待砂岩の 薄片写真

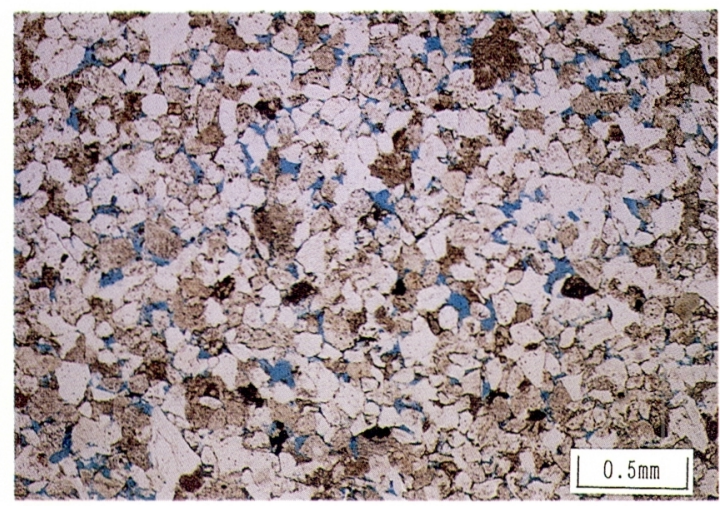

写真 -5 真三軸応力下で透水試験を行った白浜砂岩の薄片 写真

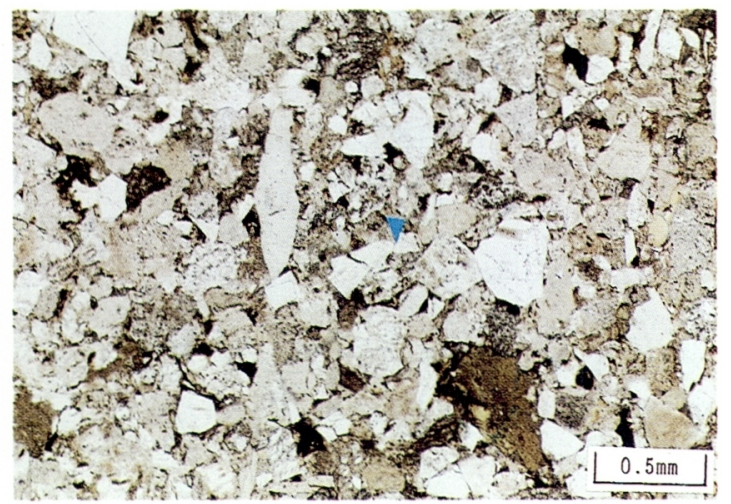
写真 -7 インタクトな和泉砂岩の薄片写真

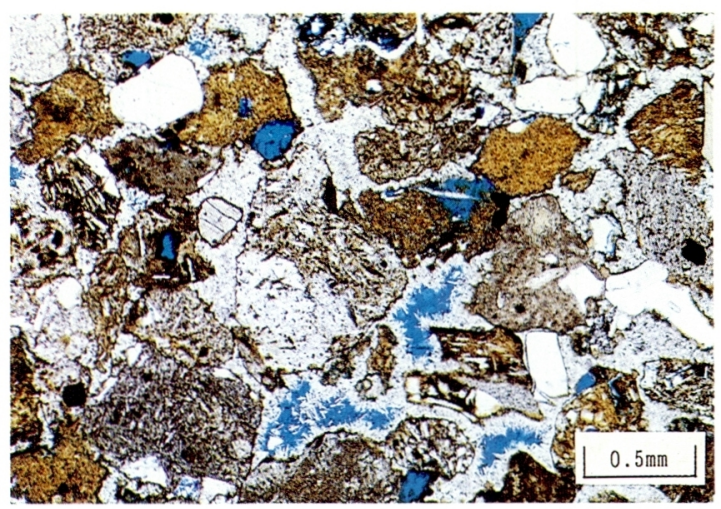

写真 -2 静水圧を $40 \mathrm{MPa}$ まで負荷したときの来待砂岩の 薄片写真

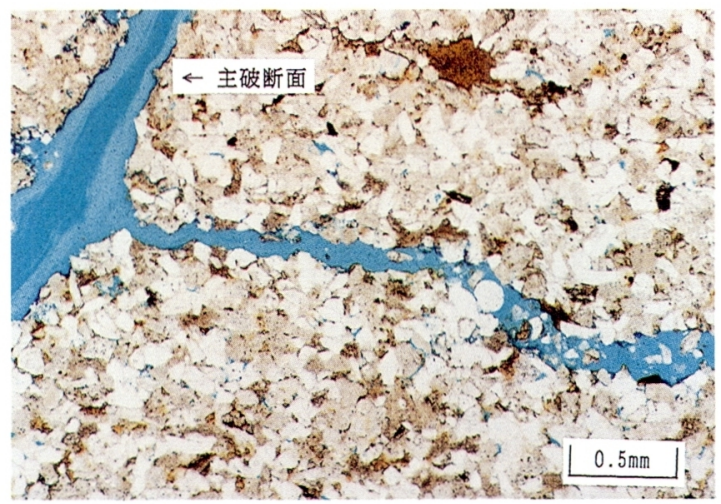

写真 -4 真三軸試験後の白浜砂岩の破断面近傍の薄片写真

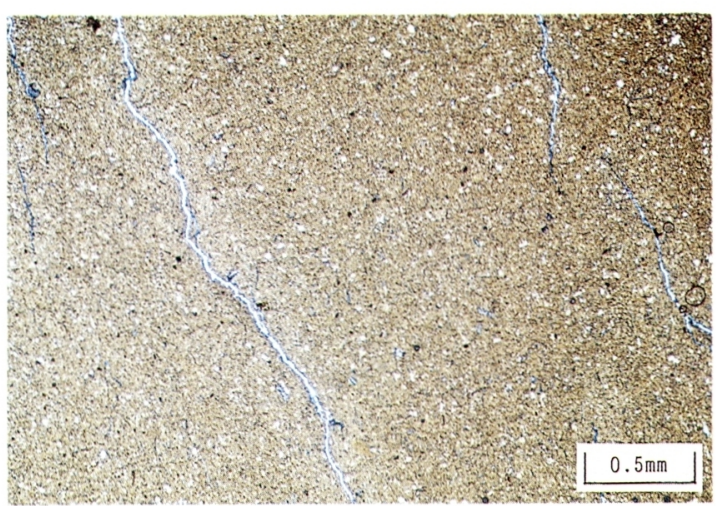

写真 - 6 封圧試験後の幌延泥岩の薄片写真

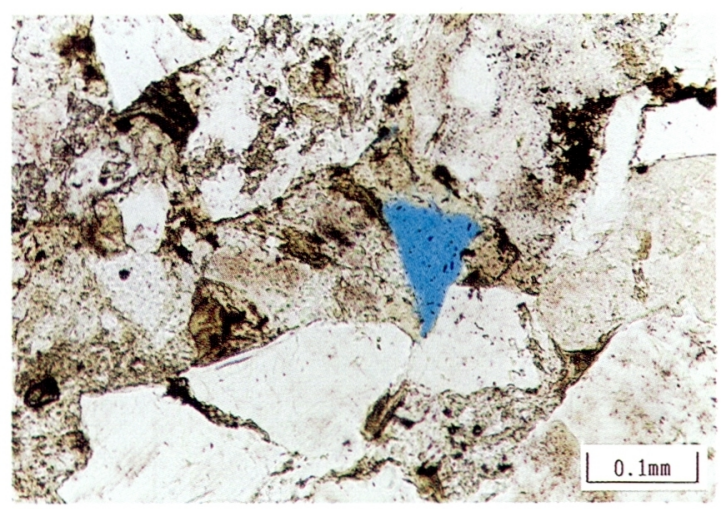

写真 -8 インタクトな和泉砂岩の薄片写真 


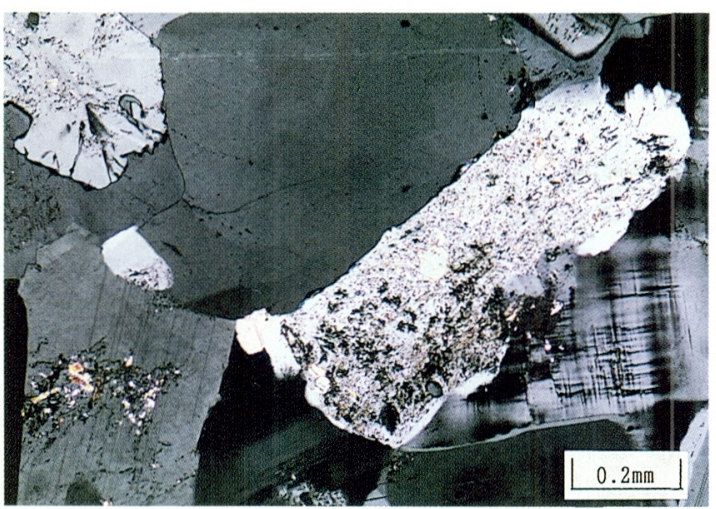

写真 - 9 インタクトな Westerly 花崗岩の薄片写真 (オープンニコル)

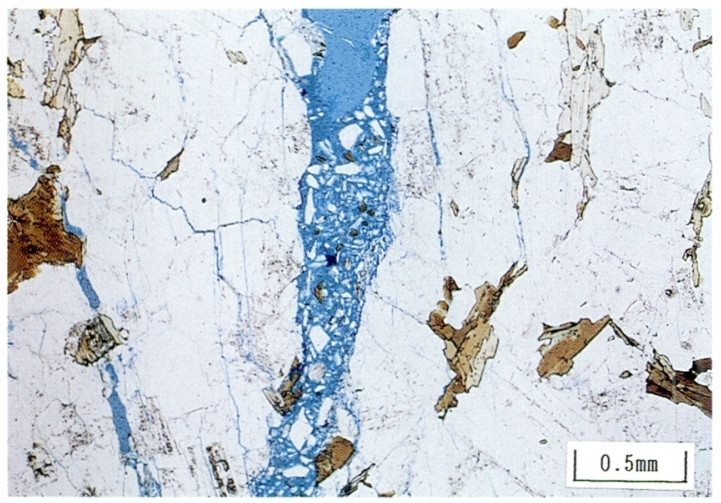

写真 -11 真三軸試験後のWesterly 花崗岩の破断面近傍 の薄片写真

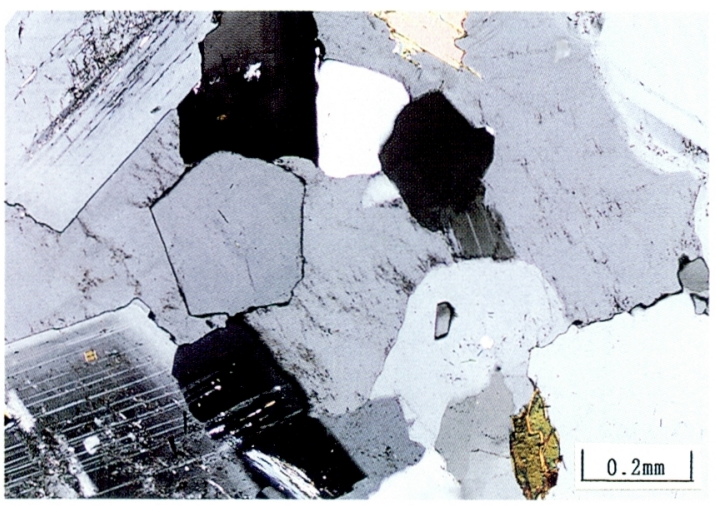

写真 -13 インタクトな庆治花崗岩の薄片写真

\section{クロスニコル)}

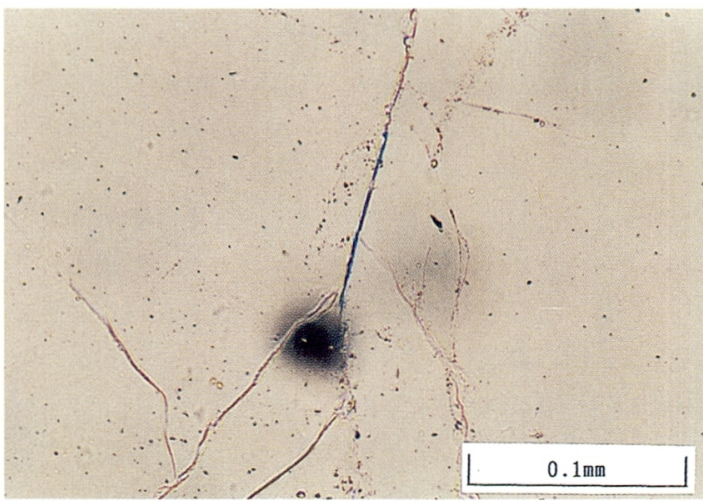

写真 - 15 インタクトな大島花崗岩の薄片写真 (オープンニコル)

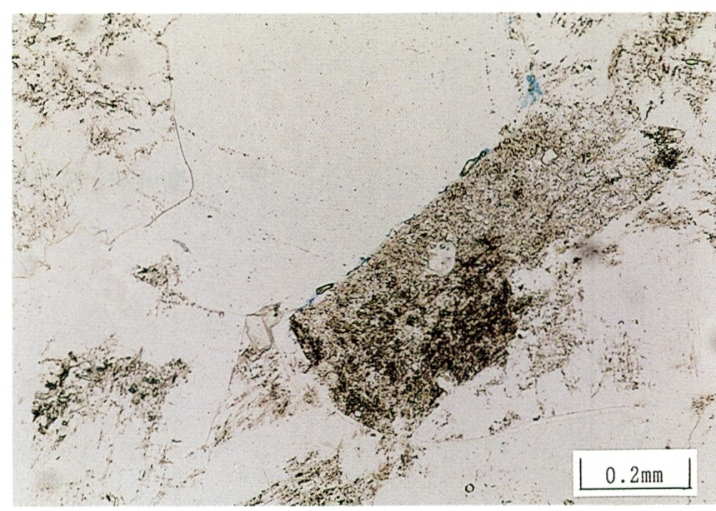

写真 - 10 インタクトな Westerly 花崗岩の薄片写真 (クロスニコル)

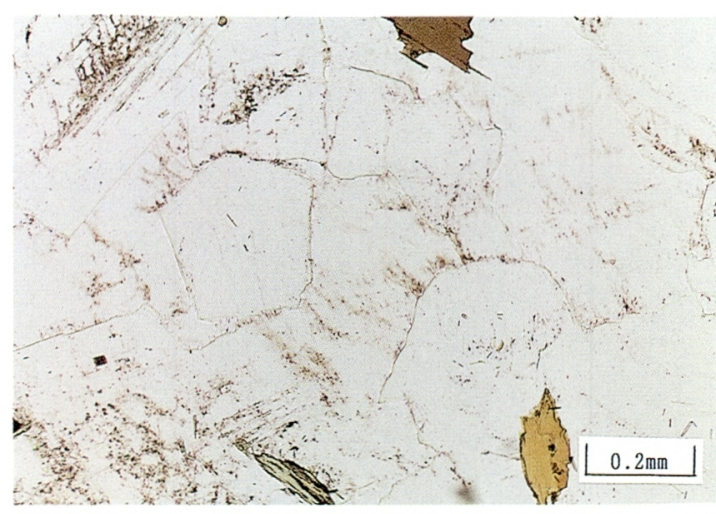

写真 -12 インタクトな庵治花崗岩の薄片写真 (オープンニコル)

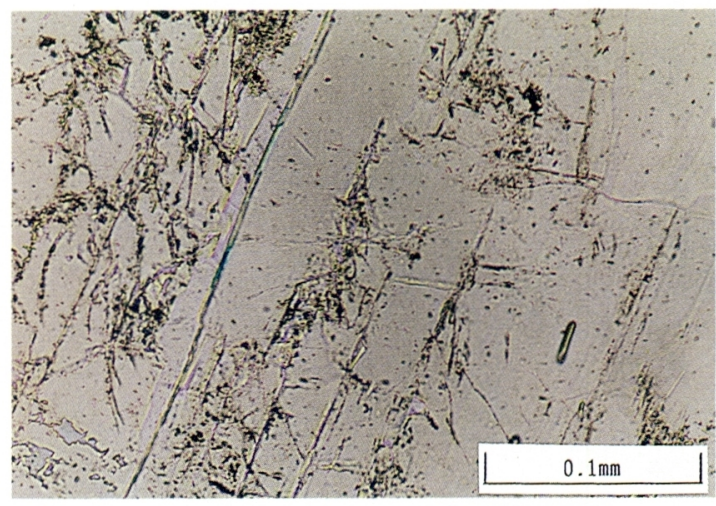

写真 -14 庵治花崗岩中の長石内の青色樹脂の様子

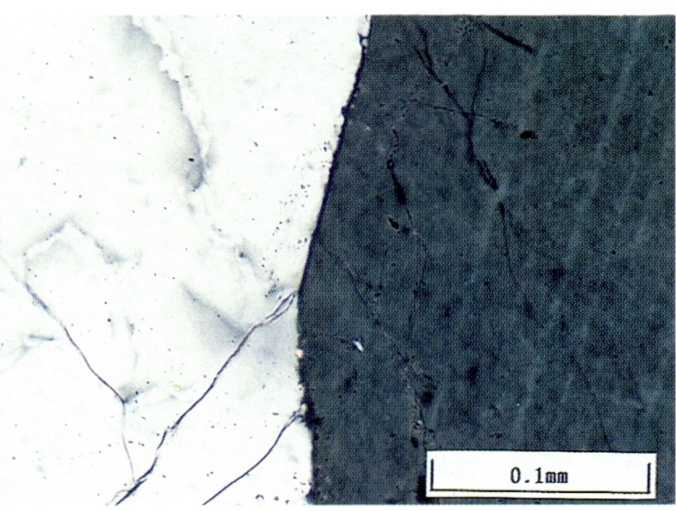

写真-16 インタクトな大島花崗岩の薄片写真 (クロスニコル) 


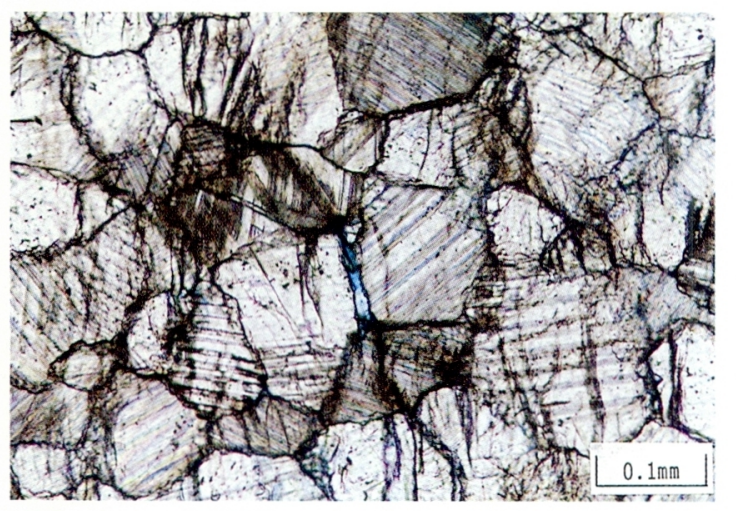

写真 -17 三軸試験後の於福大理石の薄片写真 (クロスニコル)

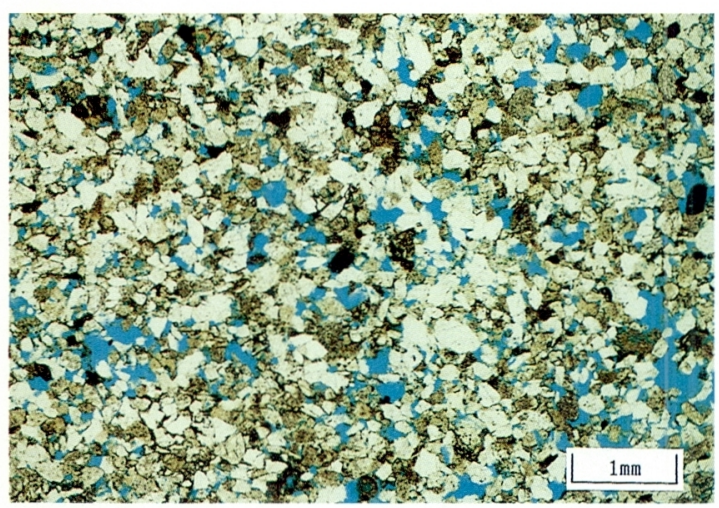

写真 - 18 インタクトな白浜砂岩の薄片写真

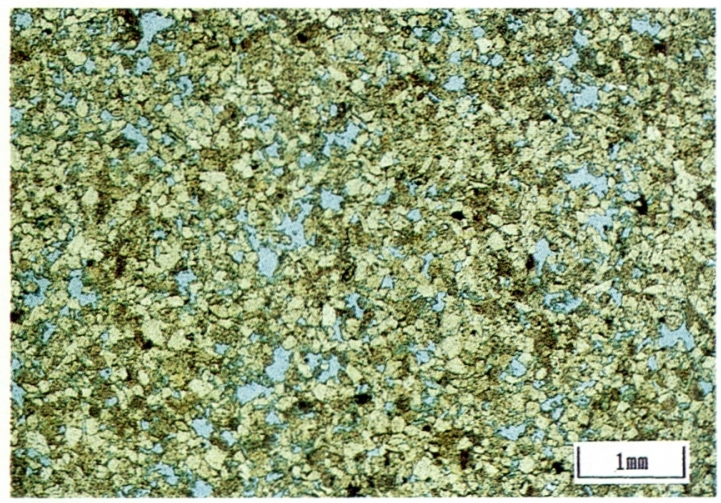

写真-19 静水圧を $49 \mathrm{MPa}$ まで負荷した白浜砂岩の薄片 写真
り，空陌率が $1 \%$ 以下，一軸圧縮強度も $2500 \mathrm{~kg} / \mathrm{cm}^{2}$ を 越える均質な砂岩である。写真からもわかるように，青 色樹脂は写真中央部を除いては全く浸透せず, 空陌らし いものも薄片全体 $(40 \mathrm{~mm} \times 27 \mathrm{~mm})$ の観察からも確 認できなかった。中央部の青色樹脂は，この領域が鉱物 粒子の脱落によってできた箇所であることを示してい る。空隙の形状としては三角形は不安定であり, 辺の軌 跡が直線的であることなどから考えて，粒子部分の脱落 と判断できる。細心の注意を払って薄片作製を実施して いるが，このような粒子の脱落もまれに生じうる。和泉 砂岩のような空隙率が $1 \%$ 以下と小さく, 続成作用を強 く受けた粒子形状の小さな岩石には同手法は適さないこ とがわかる。

写真 - 9, 10はインタクトな Westerly 花崗岩のもので ある。青色樹脂は一部の粒界で確認できたが，鉱物粒子 内の潜在亀裂（マイクロクラック）には全く確認できな かった。写真－11はWesterly 花崗岩を真三軸圧縮試験 で最終的に破壊させたものである。中央に主破断面が入 り，破断面間には小さく破砕された粒子が残されている のが認められ，破壊時のエネルギー解放の大きさを示し ている。主破断面にほほ平行で規模の小さな破断面（マ イクロクラック）が主破断面近傍に認められる。既述し た堆積岩類には認められない特徵である。

写真 $-12,13$ はインタクトな庵治花崗岩のものであ る。庵治花崗岩は, 香川県木田郡庵治町付近で産出され る日本を代表する石材の 1 つである。和泉砂岩同様, 青色樹脂は粒界・粒内とも薄片全体で確認することはで きなかったが, 写真-14に示すように, 長石内のごく 一部にわずかな青色樹脂を確認することができた。

写真 $-15,16$ は愛媛県伊予大島産の大島花崗岩の薄片 写真である。薄片全体を通じ, 石英内, 長石内の潜在亀 裂が卓越しており, 力学的な異方性が大きい岩石であ る。潜在亀裂が粒界で止まった状態を示しており，粒界 の方がより濃く青色樹脂が浸透したことがわかる。この ときの粒界の幅は10ミクロン程度である。

写真-17は山口県於福産大理石の写真である。封圧 $20 \mathrm{MPa}$ の三軸圧縮試験後の供試体である。封圧20 $\mathrm{MPa}$ においてこの大理石は延性挙動を示し, 各粒子业 イズ規模のマイクロクラックが卓越する。青色樹脂はこ の倍率では局所的に分布しているように見えるが，倍率 を上げてみるとほぼ全域に浸透していることが認められ る。したがって, この大理石の場合には, 青色樹脂が通 過できる程度の連結性のよいマイクロクラックが存在し ていたものと思われる。

以上, 砂岩 3 岩種, 泥岩 1 岩種, 花崗岩 3 岩種, 大 
理石 1 岩種の 8 岩種について青色樹脂を含浸させた場 合の薄片写真を観察してみた。インタクトな状態では和 泉砂岩では全く含浸することなく，花崗岩類は 10 ミク ロン程度のマイクロクラックならば含浸することが確か められた。しかし，同じ開口幅を持つマイクロクラック が数多く存在する中で, 特定のもののみが青色樹脂の含 浸の度合いが高かった事実は，マイクロクラックの開口 幅のみが流体の移動・浸出を決定しているのではないと いうことを示していると思われる。このようなマイクロ クラックの存在は, 流体の移動・浸出がある特定のマイ クロクラックによって支配的に行われていることの証拠 となるだろう。

青色樹脂を岩石に浸透させ，薄片を用いて岩石中のポ アやクラックの 3 次元分布を解明しようとする試みは, 多くの研究者によって実施されている。今回紹介したも のは，原理的には既往の研究によって採用された手法と 同じであるが，より細心の注意をして薄片を作り上げる ことで, 鉱物粒子の脱落や 2 次クラックの発生を極力 抑えることができた点に成果があると思う。今回実施し た供試岩石のうち，インタクトな和泉砂岩には適用でき ないことが判明したが，適用できる岩石の孔隙率の下限 值は今後事例を増やし検討することによって求められる ものと思われる。

写真 -1 から写真 -17 をでに示したように, 同手法が すべての岩種に適用できるというわけではないが，イン タクトな状態で空陌率が数\%以上の岩石には十分適用で きるものと思われる。また，主破断面を有するような破 壊後の供試体のクラックなどの観察にも適していること がわかった。この場合, 樹脂が浸透するクラックの幅は 10 ミクロンが限度と思われる。ただし, 孔隙率やマイ クロクラックの開口幅のみが青色樹脂の含漫の度合いを 決定しているのではなく，あくまでもポアやマイクロク ラックの連結性が支配していることも明らかとなった。 青色樹脂を浸透させた薄片を用いることにより，ポアと 粒子との境界がより明瞭に確認できるようになったこと は，次に述べる画像処理を実施する場合の大きなメリッ トとなっている。

\section{4. 画像処理に関して}

ここでは, 白浜砂岩の例を中心にポア状の空隙を対象 に画像処理し，それらの結果について紹介する。今回採 用した一連の画像処理システムを図ー2 に示す。ここで は，偏光顕微鏡による薄片観察を行い，岩石中に含まれ るポアの様子を撮影した写真を入力情報とした。薄片の 写真は, 最高解像度 400 DPI のカラーイメージスキャナ

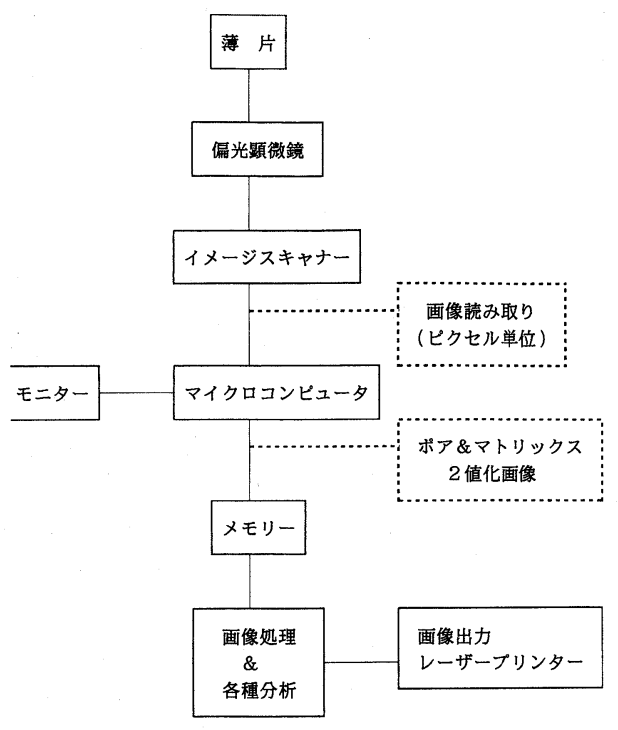

図-2 画像処理のフロー

一を介し，位置と明るさの情報を持つ画素としてコンピ ユータに取り込まれる。この際, 取り込み画像の解像 度, 中間調, 濃度補正, 色補正などの各種処理が施され る。取り込まれた画像は, 対象とする領域の及を抽出す ることができるように 2 值化処理が施される。

図-3 (a)，(b) は写真18，19を入力画像として図-2 に示された手順に従って抽出された空隙の領域（黒い領 域）とマトリックス粒子（白い領域）のバイナリーイメ ージである。この領域の大きさは実寸法で3.6 $\mathrm{mm} \times 5.2 \mathrm{~mm}$ であり, 画素の数は $328 \times 480$ となってい る。岩石中に含まれるポアやクラックの大きさおよびそ の分布形態に関する解析は，このバイナリーイメージを もとに行われる。図-3 (a)，(b) は静水圧負荷前と静水 圧 $49 \mathrm{MPa}$ 負荷後の白浜砂岩中のポアの様子をそれぞれ 示している。ポアの総面積が全体に占める割合は（a) の試験前が $6.54 \%$ であるか，（b）の試験後は $4.86 \%$ とな った。静水圧の負荷によってポアの量が減少することが このような事実からも認められる。なお，これらの詳し い結果については薛ほか30)にまとめて報告する予定で ある。バイナリーイメージでは, 空隙の領域の全体に占 める割合を 2 次元の空隙率と考えることができる。こ の空隙率は強制乾燥重量・湿潤重量・水中重量などから 求める物理的方法で得られた空隙率（以後, 3 次元の空 隙率と称する）と異なる。岩石の空隙率は, 孤立した状 態の空隙をも評価していることになる。透水試験などの 流体の移動や浸出に関連した問題では，あくまでも供試 体内の連結した空隙の割合，すなわち有効空隙率に着目 


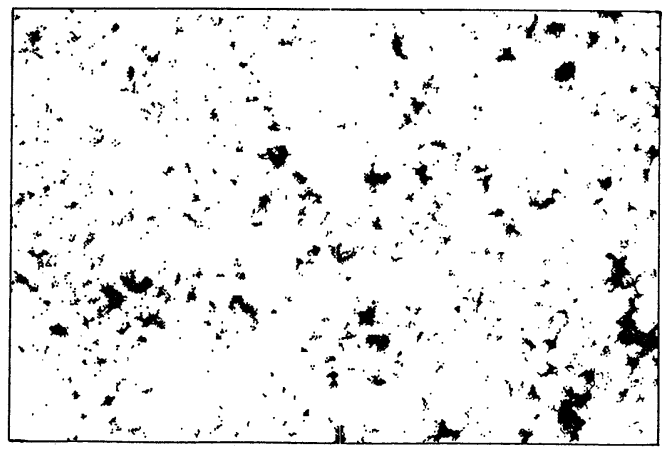

（a）静水圧㬹荷前

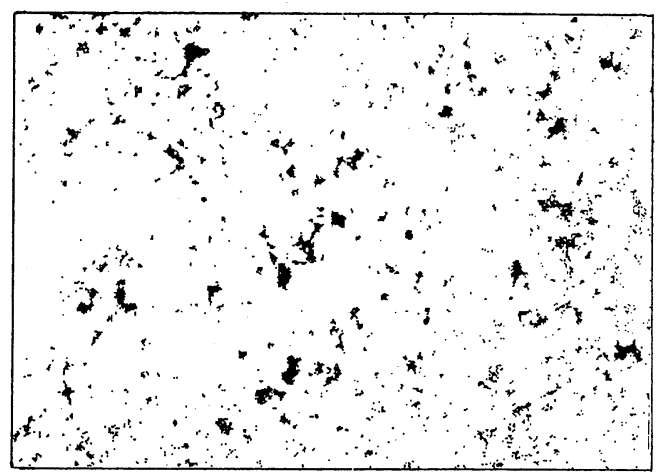

(b) 静水圧 $49 \mathrm{MPa}$ 負荷後

図-3 画像処理によって得られた 2 值化イメージ

する必要がある。有効空隙率は空隙率よりも小さな值を 示すこと，本手法では樹脂が浸透した領域のみを扱って いることなどから，イメージから求めた 2 次元の空隙 率は有効空隙率に近いものと洘えられる。

DOYEN $^{31)}$ はイメージから求めた 2 次元の空隙率の方 が物理的方法で求めた 3 次元の空隙率よりも大きくな ることを報告している。今回の白浜砂岩の空隙率は 13\%であり, イメージから求めた 2 次元の空隙率の方 が小さいという DOYEN ${ }^{31)}$ の結果と逆の関係を示した。 以下，この理由について岩石の構造上の観点および画像 処理上の観点から考えてみることにする。

岩石の構造上の観点から考えると，3 次元的な分布を しているものを 2 次元の断面で見て，その空隙率を比 較する場合，両者が異なることは当然ありうる。そこで， 3 次元の空隙率と 2 次元の空隙率が大きく異なることを 図-4のような簡単な砂岩の粒子モデルを用いて考えて みる。図 -4 は砂岩の構成粒子はその大きさが均一で, しかも粒子の配列の仕方がピラミッド状と仮定した場合 の平面図と側面図を示している。この場合の基準となる 単位あたりの孔隙率は $25.95 \%$ となる。図ー5 (a), (b)は
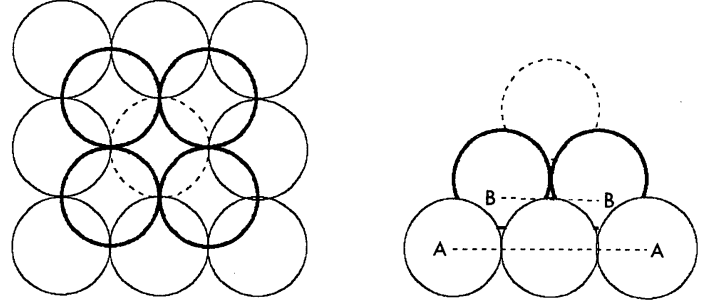

平面困

側面図

図-4 岩石の粒子配列宅デル（ピラミッド型）
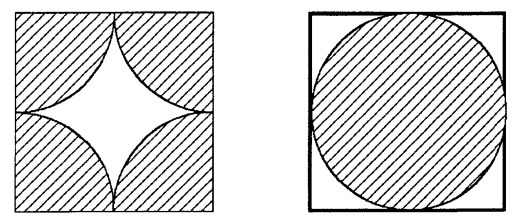

$\mathrm{A}-\mathrm{A}$ 断面
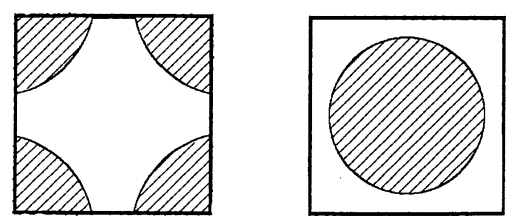

$\mathrm{B}$ - B 断面

図-5 粒子配列モデルの各断面の様子

右側は粒子の中心で見た場合，左側は空隙の中心 で見た場合。

図-4の側面図において，測線 A-A 断面, B-B 断面 で切断した場合の単位当りの平面図である。前者は断面 内に孔隙の占める割合が一番少ない場合であり，後者は 一番多い場合である。断面内の 2 次元の孔隙率はそれ ぞれ，21.46\%，34.96\%となる。右側の図は粒子の中心 で見た場合であり，同様に左側は空隙の中心で見た場合 である。2 次元の空隙率は断面によって, 3 次元で求め た空隙率よりも小さい場合も大きい場合もあり，これら の積分值が 3 次元の空隙率に相当するものと考えられ る。最も単純な場合を想定し, 3 次元と 2 次元の場合の 空隙率を計算しても, 両者はどこの断面をとるかによっ て大きく異なることが示された。実際の砂岩供試体にお いては，図-4で示されるような単純な粒子配列はむし ろ考えずらいので, 3 次元の空隙率とイメージから求め た 2 次元の空隙率との違いは, 薄片毎に異なる, ある 
いは薄片の中でも場所毎に異なると言っても良いであろ う。DOYEN ${ }^{31)}$ は, 薄片の厚さや, 薄片を作る位置の違 いによる理由を述べているが，このような理由は図 -4 のような均質な粒子の一定配列構造によってももたらさ れることが明らかである。したがって，今後薄片を用い て供試体の孔隙率等を評価する場合には，できるだけ大 きな薄片を準備し, 薄片全体について検討することが必 要であり,さらに同一供試体からより多くの薄片を作る ことも大事である。

一方, 画像処理上からこの問題を考えた場合, 2 值化 する時のしきい値の設定が重要と思われる。しかしなが ら，2 值化して得られた画像は，常に元の入力值である 写真と比べて, 両者の差が最小になるよう繰り返し 2 值化を実行している。したがって，2 值化による空隙率 の測定誤差は小さいものと思われるが，現段階では実施 例も少ないので, 今後の検討課題としたい。なお，樹脂 の漫透の程度が十分でない場合も考えられるが，薄片の 作り方のところでも述べたように, 慎重な含浸過程の繰 り返しによって，これによる可能性は少ないものと思わ れる。薄片観察中に, 樹脂の含浸が不十分と思われる空 隙の存在を確認することはできなかった。

以下, ポアの最も長い径の方向分布やポアを棈円近似 した時のアスペクト比の分布などについて述べることに する。

図-6 は図-3のバイナリーイメージより得たポアの 最も長い径の方向と各ポアの周囲長との関係を示してい る。静水圧 $49 \mathrm{MPa}$ まで負荷した (b)後では, 試験前 (a) に存在した $20^{\circ}$ と $170^{\circ}$ 付近の $2 つ$ つピークがくなって いる。ポアと同じ面積を持つ楕円を仮定し，アスペクト 比の分布を示したのが, 図-7である。静水圧負荷前 (a)に存在した面積が大きく, しかも，アスペクト比の 小さいポアは負荷後 (b)閉鎖していることがわかる。あ る大きさのアスペクト比 $\alpha$ を持つクラックが完全に閉 鎖する静水圧 $P_{\mathrm{c}}$ は, WALSH $(1965)^{32)}$ によれば,

$$
P_{\mathrm{c}}=\pi E \alpha / 4\left(1-v^{2}\right)
$$

で与えられる。ここで，Eは媒質のヤング率，vはポア ソン比を示す。上式からも容易に理解できるように, 閉 鎖する圧力 $P_{\mathrm{c}}$ はアスペクト比 $\alpha$ と比例関係にあるの で, ある任意の静水圧を媒質に与えるとアスペクト比の 小さいものから順に閉鎖することになる。ちなみに，今 回の実験では, 静水圧 $49 \mathrm{MPa}$ の負荷に対し, 体積ひず みは $0.8 \%$ の収縮量を示している。したがって, 前述し た画像処理の結果は, 試験後の供試体の薄片を用いては いるが, 静水圧の増加に伴う内部組織の変化を正確に反
映していることになる。

真三軸応力下で最大主応力および中間主応力方向の透 水係数を測定した供試体の画像処理結果の一部について 以下に示す。用いたデータは写真 -5 を画像処理したも のである。図-8 はポアの最も長い長軸の值と短軸の平 均長さとの関係を示している。長軸が大きくなるほど, 短軸の長さも大きくなる傾向が認められる。図-9はポ アの長軸の方位分布とそれらの画像全体に占める割合を 示している。方位は大きく中間・最小主応力方向の 2 つに分かれているのが認められる。この試験では，中間 ・最大主応力を段階的に変えているので，この結果だ けからでは, 応力の変化とポアの長軸の方位分布との関 連については言及できない。図ー10はポアを棈円近似 したときのアスペクト比とそれらが画像全体に占める割 合を示している。アスペクト比が1.0すなわち球状のも のが卓越していたことがわかる。なお，これらの詳しい 結果については杉田ほか33)に述べられている。

以上, 今回用いた画像処理の構成とデータ整理の内容 について簡単に述べた。画像処理上重要な概念である連 結性の問題, エッジ検出の問題や輪郭の処理, 線の抽出 などの各種処理方法が最終的な出力画像に与える影響に 関しては，今後十分な検討がなされなければならない。 青色樹脂を混合した薄片を用いる観察方法では, 主にポ ア状の領域の抽出に優れていることがわかった。西山ほ か25)の蛍光染料を充填した供試体に紫外線を照射する 方法では, 数ミクロン以上のマイクロクラックの検出に 優れていることが報告されている。対象物がポアかマイ クロクラックかによる画像処理上の問題点は, 今後多く の事例研究を積み上げていく過程で解決されなければな らない。

\section{5. 今後の課題}

薄片を用いた岩石中のポアの形態から, 岩石の流体輸 送特性を推定する試みは多くの研究者によって行われて いる。BERRYMAN and BLAIR ${ }^{34)}$ は SEM 画像中の 2 点間の空間相関関数を用いて空隙率とポアの比表面積を 求め, Kozeny-Karmanの式から透水係数を求めてい る。こうして得られた透水係数は, 用いた空隙率や比表 面積の倍率に依存することを報告している。また，空隙 率では50倍から200倍の倍率の画像を用いて求めた場合 が，実際に用いた場合と良く一致することを報告してい る。KOPLIK et al. . ${ }^{35)}$ は Massilion 砂岩の薄片から, 電 気回路の抵抗と同じように，空隙のネットワークモデル をつくり, 岩石の透水係数の評価を行っている。こうし て得られた透水係数は実際に測定した值よりも10倍も 


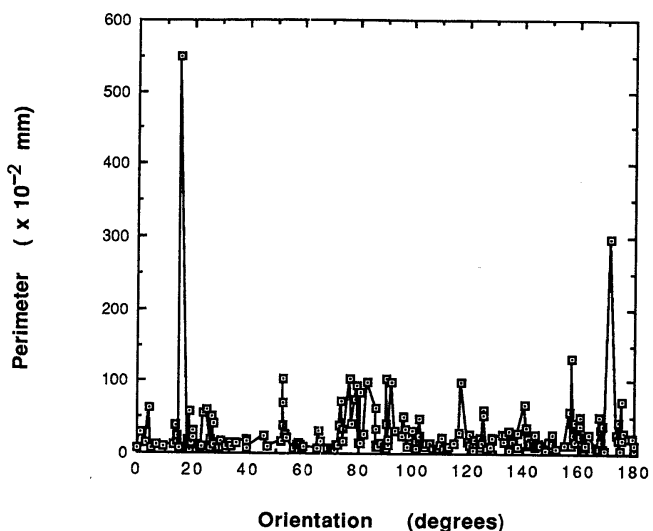

（a）静水圧負荷前

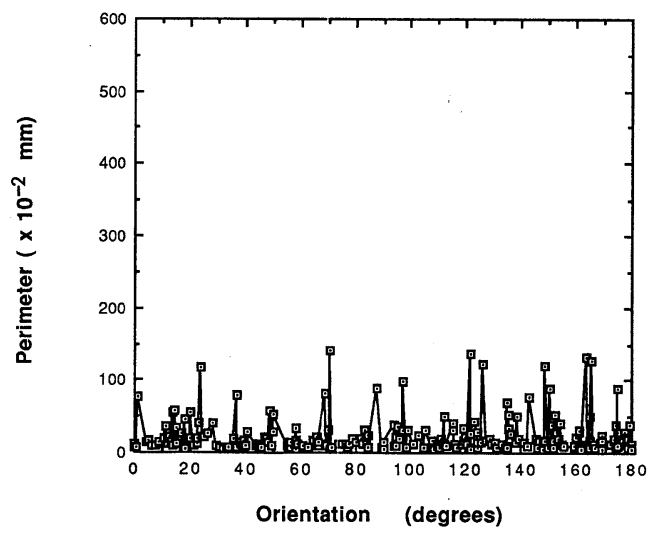

（b）静水圧 $49 \mathrm{MPa}$ 負荷後

図-6 ポアの長径の方向と周囲長の関係

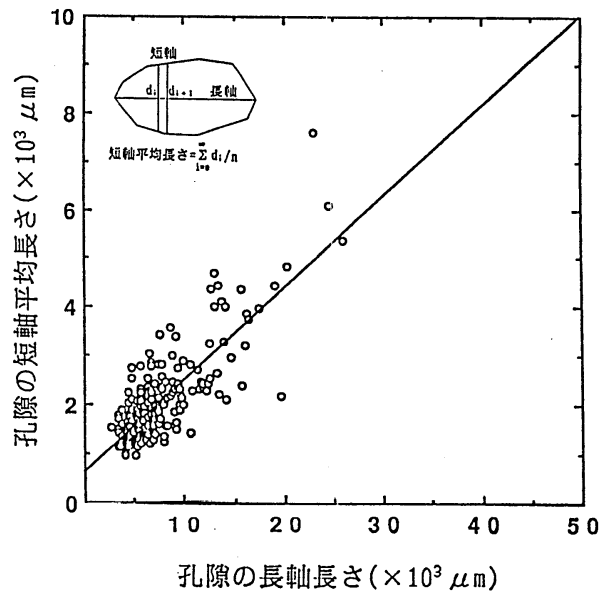

図-8 ポアの長軸長さと短軸平均長さとの関係

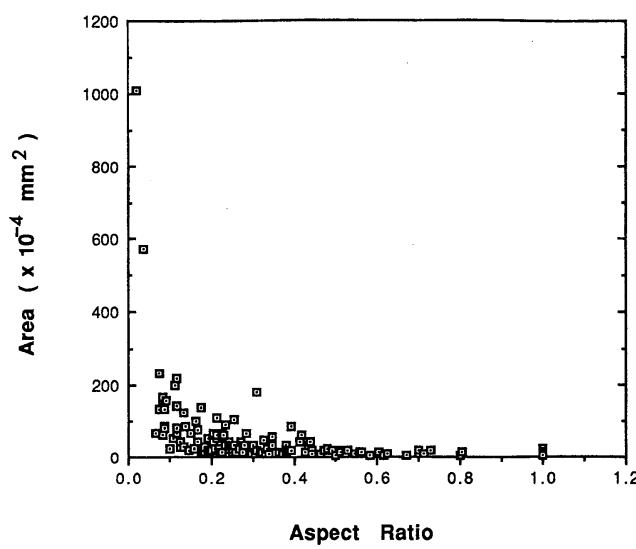

（a）静水圧負荷前

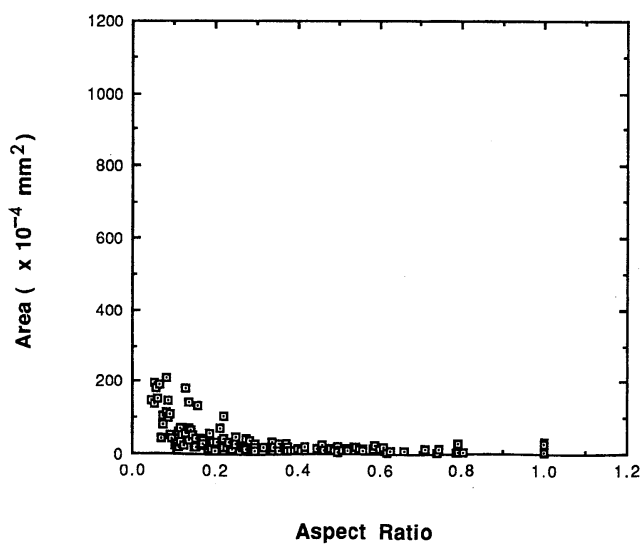

（b）静水圧 $49 \mathrm{MPa}$ 負荷後

図-7 アスペクト比の分布

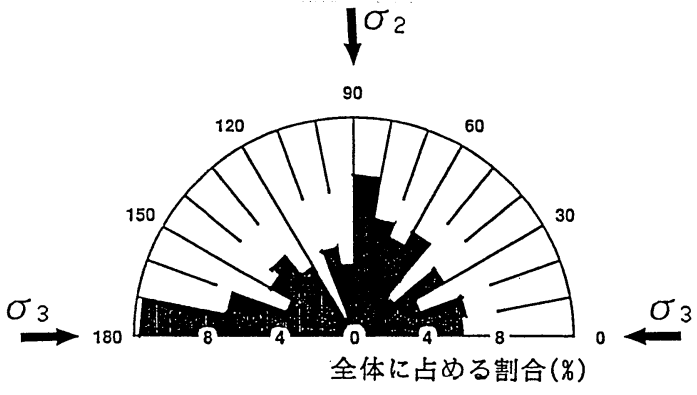

図-9 ポアの方位分布と全体に占める割合 


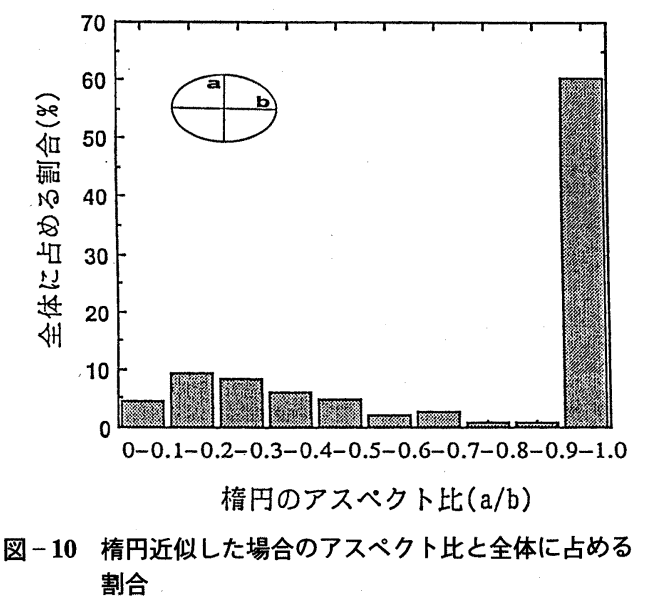

大きかった。この理由として,ごく限られた領域の薄片 を用いていることや岩石本来の不均一性等, あるいは岩 石には初期構造異方性があること, 計算には棈円柱を仮 定しているが，実際のポアにはこのような単純な形をし たものが少ないなどの理由を挙げている。DOYEN ${ }^{311}$ 透水係数の变化を空隙率の関数として評価する手法につ いて述べている。この場合の空陌率溥片で観察される 空隙率を定量的に評価している。同様の研究に $\mathrm{EHRLICH}^{36)}$ がある。彼は巨視的な岩石の輸送特性と throat（ポアとポアをつなぐクラック状の通路）サイズ のヒストグラムや 2 次元のポア連結性とは良い相関が あることを述べている。

ポアの 3 次元分布形態を直接観察しょうと, WARDLAW ${ }^{37}$, PITTMAN and DUCHANKO ${ }^{38}$ は岩石 のマトリックス部分を溶かし, 樹脂を充填したポアの骨 格のみを取り出すことに成功している。また，岩石にウ ッド合金を圧入し，反射型顕微鏡を用いてポアの 3 次 元分布を観察した RINK and SCHOPPER ${ }^{399}$ の例もあ る。

画像から得られる透水係数は, 実験によって得られる 值よりも大きくなる。この主原因はポアなどのネットワ 一クを 3 次元で定量的に評価する手法が確立していな いためと思われる。今後, 2 次元の画像情報から 3 次元 におけるポアのネットワーク情報を引き出すための理論 と, より多くのデータの蓄積が必要となるだろう。筆者 らは打もに堆積岩の透水特性について, 種々の応力条件 下での透水係数を測定している。さらに，透水特性をよ り詳細に把握するために, 变形特性や弾性波伝播特性む 同時に測定している。今後は, 画像処理から得られる結 果をもとに, これら各種物理量との相関を比較・検討 し，ポアの 3 次元情報の蓄積を図るつもりである。
【謝辞】地質調查所地殼物理部杂原保人氏には画像処 理装置一式をお借りした。ここに記して，感謝いたしま す。

\section{参 考 文 献}

1）小出 ヒ・星野一男(1967) : 三軸変形下の岩石中の微小割 れ目の発達について, 地震, 第20巻, pp. 85-97.

2) WILLARD, R. J., and MCWILLIAMS, J. R. (1969): Microstructural techniques in the study of physical properties of rock, Int. J. Rock Mecha. Min. Sci., Vol.6, pp. 1-12.

3) PENG, S., and PODNIEKS, E. R. (1972): Relaxation and the behavior of failed rock, Int. J. Rock Mecha. Min. Sci., Vol. 9, pp. 699-712.

4) HALLBAUER, D. K., WAGNER, H. and COOK, N. G. W. (1973): Some observations concerning the macroscopic and mechanical behavior of quartzite specimen in stiff, triaxial compression test, Int. J. Rock Mecha. Min. Sci., Vol. 10, pp. 713-726.

5) DUNN, D. E., LAFOUNTAIN, L. J., and JACKSON, R. E. (1973): Porosity dependence and mechanism of brittle fracture in sandstones, J. Geophys. Res., Vol. 78, No. 14, pp. 2403-2417.

6) BONBOLAKIS, E. G. (1973): Study of the brittle fracture process under uniaxial compression, Tectonophysics, Vol. 18, pp. 231-248.

7) OLSSON, W. A. (1974): Microfracturing and faulting in a limestone, Tectonophysics, Vol. 24, pp. 277-285.

8) MOSHER, S., BERGER, R. L., and ANDERSON, D. E. (1974): Fracturing characteristics of two granites, Rock Mechanics, Vol. 7, pp. 167-176.

9) PENG, S. S. (1975): A note on fracturing propagation and time dependent behavior of rocks in uniaxial tension, Int. J. Rock Mecha. Min. Sci., Vol. 12, pp. 125-127.

10) OLSSON, W. A., and PENG, S. S. (1976): Microcrack nuclation in marble, Int. J. Rock Mecha. Min. Sci., Vol. 13, pp. $53-59$.

11) Hirotaka UI (1976): Experimental study of the mechanical properties and microfracturing of some brittle rocks by compression tests, J. Earth Sci. Nagoya Univ., Vol. 23/24, pp. 57-91.

12) WEINBRANDT, R. M., and FATT, I. (1969): A scanning electron microscope study of the pore structure of sandstone, J. Petrol. Technol., Vol. 21, pp. 543-548.

13) TIMUR, A., HEMPKINS, W. B. and WEINBRANDT, R. M. (1971): Scanning electron microscope study of pore systems on rocks, J. Geophys. Res., Vol. 76, No. 20, pp. 4932-4948.

14) PENG, S. S., and JOHNSON, A. M. (1972): Crack growth and faulting in cylindrical specimens of Chelmsford granite, Int. J. Rock Mecha. Min. Sci., Vol. 9, pp. 37-86.

15) SPRUNT, E. S., and BRACE, W. F. (1974): Direct observation of microcavities in crystalline rocks, Int. J. Rock 
Mecha. Min. Sci., Vol. 11, pp. 139-150.

16) MONTGOMERY, C. W. and BRACE, W. F. (1975): Micropores in Plagioclase, Contrib. Miner. Petrol., Vol. 52, pp. 17-28.

17) TAPPONNIER, P., and BRACE, W. F. (1976): Development of stress-induced microcracks in Westerly granite, Int. J. Rock Mecha. Min. Sci., Vol. 13, pp. 103-112.

18) HADLEY, B. C. (1976): Comparison of calculated and observed crack densities and seismic velocities in Westerly granite, J. Geophys. Res., Vol. 81, pp. 3484-3494.

19) KRANTZ, R. L. (1979): Crack growth and development during creep of Barre granite, Int. J. Rock Mecha. Min. Sci., Vol. 16, pp. 23-35.

20) KRANTZ, R. L. (1979): Crack-crack and crackpore interactions in stressed granite, Int. J. Rock Mecha. Min. Sci., Vol. 16, pp. 37-47.

21) HOWARTH, D. F. (1987): The effect of pre existing microcracks on mechanical rock performance in sedimentary and crystalline rocks, Int. J. Rock Mecha. Min. Sci., Vol. 24, No. 4, pp. 223-233.

22) BATZLE, M. L., SIMMONS, G., and SIEGFRIED, R. W. (1980): Microcrack closure in rocks under stress: direct observation, J. Geophys. Res., Vol. 85, No. B12, pp. 7072 7090 .

23) GARDNER, R. D, and PINCUS, H. J. (1968): Fluorescent dye penetrants applied to rock fractures, Int. J. Rock Mecha. Min. Sci., Vol. 5, pp. 155-158.

24) KOTTE, J. J., BERCZES, Z. G., GRANBERG, J. and SELDENRATH, Th. R. (1969): Stress-strain relations and breakage of cylindrical granitic rock specimens under uniaxial and triaxial loads, Int. J. Rock Mecha. Min. Sci., Vol. 6, pp. 581-595.

25）西山 孝・楠田 啓・北川元紀(1990) : 蛍光剂を添加した 樹脂による微小割れ目の視覚化と自動抽出, 資源・素材学 会誌, 106巻, 10号, pp. 19-25.

26）安部正治(1988) : 岩石の空隙を薄片で探る, 地質ニュース, 404 号, pp. 60.

27）薛 自求 ·大和田朗 - 高橋 学・楠瀬勤一郎 - 石島洋二 (1991) : 砂岩の内部構造とその透水特性について, 地質二 ュース, 439号, pp. 50-53.
28）石島洋二・薛 自求・高橋 学(1991)：静水圧下におけ る砂岩の透水特性について, 第 8 回岩の力学国内シンポシ ウ厶講演論文集, pp. 393-398.

29) 石島洋二・薛 自求・高橋 学(1991)：新第三紀堆積岩 の透水挙動と等価管路モデルによる解釈, 応用地質, Vol. 32 , No. 5, pp. 1-12.

30) 薛 自求・石島洋二・高橋 学 (1992)：砂岩の透水特性 と内部構造資源と素材，1992年11月号，pp. 769-775.

31) DOYEN, P. M. (1988): Permeability, conductivity and pore geometry of sandstone, J. Geophys. Res., Vol. 93, No. B7, pp. 7729-7740.

32) WALSH, J. B. (1965): The effect of cracks on the compressibility of rock, J. Geophys. Res., Vol. 70, pp. 381-389.

33）杉田 裕- 石島洋二 - 高橋 学(1992)：真三軸応力下に おける白浜砂岩の透水係数に及ほす中間主応力の影響につ いて, 平成 4 年度資源・素材学会春季大会講演予稿集, pp. 31-32.

34) BERRYMAN, J. G., and BLAIR, S. C. (1986): Use of digital image analysis to estimate fluid permeability of porous materials: Application of two point correlation functions, J. Appl. Phys., Vol. 60, No. 6, pp. 1930-1938.

35) KOPLIK, J., LIN, C., and VERMETTE, M. (1984): Conductivity and permeability from microgeometry, J. Appl. Phys., Vol. 56, No. 1, pp. 3127-3131.

36) EHRLICH, R., CARBTREE, S. KENNEDY, S. and CANNON, R. (1984): Petrographic image analysis of reservoir pore complexes, J. Sediment. Petrology, Vol. 54, No. 4, pp. 1365-1378.

37) WARDLOW, N. C. (1976): Pore geometry of carbonate rocks as revealed by pore cases and capillary pressure, $\mathrm{A}$. A. P. G. Bull., Vol. 60, pp. 245-257.

38) PITTMAN, E. D. and DUCHANKO, R. W. (1970): Use of pore casts and scanning electron microscope to study pore geometry, J. Sed. Pet., Vol. 40, pp. 1153-1157.

39) RINK, M., and SCHOPPER, J. R. (1978): On the application of image analysis to formation evaluation, The $\mathrm{Log}$ Analyst, Jan.-Feb., pp. 12-22.

（1992年 4 月 21 日受付，1992年 7 月29日受理） 